Criação 


\title{
O Nordeste e sua música
}

$\mathrm{N}$ O COMEÇO DA DÉCADA DE 70, Marcus Pereira e eu decidimos fazer um mapeamento musical do Brasil. A idéia, consumada até $1975 \mathrm{em}$ quatro coleções discográficas, era documentar as manifestações mais representativas das várias regiões brasileiras. Todo o projeto, com sofisticados recursos técnicos, dava seqüência ao que Mário de Andrade, munido apenas de lápis e papel, iniciara 40 anos antes.

Quando já estava gravada a coleção Música Popular do Nordeste pedi a cinco intelectuais da região, atentos observadores da vida comunitária, que escrevessem a respeito dos principais gêneros documentados. Ariano Suassuana produziu um texto explicativo sobre cantorias de viola e literatura de cordel; Paulo Cavalcanti encarregou-se do frevo; Renato Carneiro Campos discorreu sobre côcos e bandas de pífanos; Euricledes Formiga comentou as emboladas; Jaime Diniz analisou as danças populares, especialmente as cirandas; e Hermilo Borba Filho dissertou, de cátedra, sobre o bumba-meu-boi.

Também coube ao Hermilo planejar toda a pesquisa de campo empreendida pelo Quinteto Violado. O material escrito continua rigorosamente atual e, em seu conjunto, forma um vigoroso ensaio sobre a cultura popular nordestina - razão que determinou o seu oportuno aproveitamento em ESTUDOS AVANÇADOS. Assim, o que parecia condenado ao degredo nas estantes dos colecionadores vem novamente à luz.

Resgata-se do esquecimento uma reflexão que pode suscitar novas pesquisas, sempre necessárias. Instala-se, no meio acadêmico, uma hipótese de trabalho sobre o nosso mais criativo compositor de todos os tempos - o povo brasileiro. (Aluizio Falcão, jornalista, é assessor de imprensa da Pró-Reitoria de Cultura e Extensão da USP).

\section{Violeiros e cirandas: poesia improvisada}

\author{
ARIANO SUASSUNA
}

A POESIA POPULAR DO NORDESTE pode se classificar em dois grupos bem caracterizados: a literatura de cordel e a poesia improvisada dos cantadores. $\mathrm{O}$ nosso romanceiro é, sem dúvida, originário do ibérico, mas tem hoje fisionomia própria, inclusive pela riqueza e variedade das formas de estrofes usadas. Dessas 
estrofes, as mais utilizadas são a sextilha, a décima de sete sílabas e o martelo agalopado, décima de dez sílabas cuja estrutura é a mesma usada no século de ouro na Península Ibérica.

Tais estrofes são as mais importantes tanto nos romances quanto nos desafios da poesia improvisada, existindo ainda, porém, o mourão, o galope à beiramar, o martelo gabinete (sextilha de dez sílabas) entre outras formas menos importantes. Entretanto, apesar de se tornarem cada vez mais raros, ainda encontramos no sertão alguns romances ibéricos ou iberizantes compostos na forma monorrímica.

A cantoria, ou desafio, é a forma usada para a poesia improvisada. Dois cantadores, de viola em punho, às vezes durante toda uma noite, improvisam à maneira dos tensons provençais. O que existe de melhor nesses desafios é o tom jocoso, satírico.

- Vá me buscar um carneiro que seja mocho e pelado, com uma estrela na testa, com os quatro pés manchados, de rabo branco e comprido e com o couro malhado.

- Meu colega, me desculpe, você errou o terreiro.

Vá bater em outra porta, procurar noutro roteiro: encomenda como essa só feita ao pai-de-chiqueiro

Esse tom satírico e jocoso, aliás, reaparece também na literatura de cordel, nos romances compostos, impressos em folhetos e vendidos nas feiras. Os ciclos desse romanceiro podem ser assim agrupados: ciclos heróico; maravilhoso; religioso e de moralidades; cômico, satírico e picaresco; histórico e circunstancial; de amor e fidelidade. No ciclo cômico, satírico e picaresco reaparece o mesmo tom jocoso, às vezes beirando a obscenidade, como sempre acontece nas formas de literatura popular. Disso é exemplo a seguinte sextilha, do cantador paraibano Firmino de Paula e citada por Zita de Andrade Lima:

Atirou-lhe à queima-roupa

porém naquele momento

o menino desviou-se

e veloz igual ao vento

deu-lhe um grande pontapé

no valor do casamento. 
No ciclo heróico, constituído pelos romances épicos e trágicos e, principalmente, pelas gestas do cangaço, encontramos estrofes como esta:

O Alferes pegou do rifle, ficou o mundo tinindo, era o dedo amolegando o fumaceiro cobrindo batendo as balas em Vilela, voltando prá trás, zunindo.

Às vezes, porém, no ciclo heróico, no meio de um romance épico - ou em que se misturam o épico e o maravilhoso - como em A chegada de Lampeão no inferno, aparece o cangaceiro heróico, como se fosse um sausão sertanejo, armado com uma caveira de boi; o cantador aproveita para misturar ao tom heróico um acento cômico, como na seguinte estrofe de sete pés:

Lampeão pode pegar

uma caveira de boi

Sacudiu na testa dum, ele só fez dizer: Oi!

Ainda correu dez braças e caiu, enchendo as calças, mas eu não sei do que foi!

No ciclo cômico, satírico e picaresco, encontramos, às vezes, títulos de sabor clássico como: A desventura de um corno ganancioso, que parece nome de um conto de Boccaccio. O que, aliás, não é de admirar, por encontrarmos, no romanceiro nordestino, devidamente versadas, a História de dona Genevra, tirada do Decameron, e a História de Romeu e Julieta. No ciclo do maravilhoso, encontramos histórias do tipo A moça que virou cobra e $A$ mãe de calor de figo, como também todas "as pelejas em que o Diabo aparece". O Romance do pescador que tinha fé em Deus é do ciclo religioso e de moralidades. No ciclo histórico e circunstancial agrupam-se os comentários dos poetas populares aos acontecimentos do dia: é o caso do folheto A renúncia do presidente Jânio Quadros.

A importância do romanceiro popular do Nordeste é imensa e cresce a cada dia. Quando não sua forma, seu espírito está presente em toda a melhor literatura nordestina, bastando citar, no romance, o nomes de José Lins do Rego e Guimarães Rosa, ou de Joaquim Cardozo e João Cabral de Melo Neto, na poesia, entre os que criaram sua obra na linhagem do romanceiro para mostrar como essa literatura popular é importante para que se entenda a Arte brasileira e o próprio Brasil. É que, com a História de Carlos Magno e os doze pares de França e outros vestígios do romanceiro carolíngio, assim como com histórias européias, árabes etc., o romanceiro nordestino é uma espécie de ligação entre a tradição mediterrânea e o povo brasileiro de hoje. 
Em sua poesia encontramos décimas quase surrealistas, como esta:

No tempo em que os ventos suis

faziam estragos gerais

fiz barrocas nos quintais

semeei cravos azuis.

Nasceram esses tafuis amarelos como cidro

Prometi a Santo Izidro

levá-los, quando lá for

com muito jeito e amor

em uma taça de vidro.

Ou, então, martelos como este.

Quando as tripas da terra mal se agitam

e os metais derretidos se confundem

e os escuros diamantes que se fundem

das crateras ao ar se precipitam

as vulcânicas ondas que vomitam

grossas bagas de ferro incendiado

em redor deixam tudo sepultado

só com o som da viola que me ajuda,

treme o sol, treme a terra, o tempo muda

eu cantando o martelo agalopado.

E um romanceiro que tem versos como este não precisa de mais nada para demonstrar importância.

\section{Frevo}

PAULO CAVALCANTI

FREVo - música e forma de dança - é característico de Pernambuco. Multidões em reboliço no quente aperto das ruas e dos salões de baile, nos dias de Momo, são os agentes de sua manifestação, o Carnaval, tornando-se quase anódino fora dele.

As raízes do frevo estão na modinha, no dobrado militar, na quadrilha, na polca e no maxixe, numa seqüência de transformações que o poder de criação do povo, da canalha da rua, da ralé, do pé rapado ou da massa adaptou à sua própria índole, como forma de extravasar os seus mais ardentes anseios de liberdade.

No início, o frevo era somente a música - o desfile marcial pelas ruas do 
Recife, arrastando consigo, nos becos e travessas estreitas e sombrias da velha capital pernambucana, o fervor de multidões arrebatadas.

A coreografia do frevo - o passo - nasceu da impetuosidade mesma da música, dinâmica, fogosa, agitada. "As duas coisas se foram inspirando uma na outra - e completaram-se", conforme observou Valdemar de Oliveira, mestre na matéria.

A partir do momento em que música e forma de dança se identificaram, num processo de interação da mais pura criatividade popular, o Carnaval de Pernambuco começou a ganhar as suas peculiaridades, fanfarras e bandas marciais desfilando nas ruas, seguidas da massa de foliões se requebrando na frevança das marchas que, dia a dia, se distanciavam de suas matrizes ortodoxas, para assimilar e plasmar, por fim, no ritmo e no desenvolvimento melódico, a cor inconfundível de hoje.

No princípio, o frevo não tinha letra. E nem podia tê-la, com o imprevisto de seus andamentos, os altos e baixos da pauta musical, os trechos curtos de límpidas e corridas melodias, de mistura com as paradas instantâneas, os freios, as síncopes, formando um conjunto, uma tessitura de sons e compassos que a estridência dos trombones, clarins, pistons, clarinetes e outros instrumentos metálicos ia forjando para amoldar à forma de dança, o passo, o conteúdo da música.

Foi da improvisação criadora desses três elementos - a música, a forma de interpretá-la e o modo de dançá-la, no passo - que resultou o frevo, de genuínas fontes populares, nas quais a erudição jamais teve campo, em qualquer dos tríplices fatores.

Na opinião de Rui Duarte, apaixonado estudioso do problema, as modalidades do frevo hoje existentes - o frevo-canção e o frevo-de-bloco - são descaracterizações da música pernambucana. "Foram uns jornalistas e intelectuais que entenderam que frevo tinha de apresentar uma letra, quando a música, pela sua própria natureza, não foi feita para ter a parte de canto".

Pensamos de modo contrário. Qualquer dos gêneros do frevo é legítimo, desde que conserve, como realmente conserva, os tons e ritmos iniludíveis da primitiva marcha-frevo dançada por capoeiras e valentões do Recife nos fins do século passado, quando as condições histórico-sociais permitiam um clima de democratização de raças e classes nos dias de carnaval.

Depois, com a divulgação e popularização do rádio e das vitrolas portáteis, a marchinha e o samba carioca entraram a concorrer com o frevo pernambucano, sem letra. Foi o tempo em que, por outro lado, o passo deixou de ser visto como dança bastarda, para invadir os salões dos clubes sociais do Recife, quase fechados, da velha aristocracia da cana de açúcar e de seus remanescentes.

Se, nas ruas, entre um frevo e outro, ao indispensável descanso das orquestras e fanfarras arquejantes, o povo também precisando enxugar a camisa, já 
começava a botar letra na marcação rítmica dos bombos e tarós, cantando, em coro, o “Tão pequeno, chapéu tão grande! Tão pequeno, chapéu tão grande!" como, nos dias de hoje, nas mesmas circunstâncias, os foliões dos clubes sociais imitam os surdos compassos dos instrumentos de percussão, ao estribilho "Ou dá ou desce! Ou dá ou desce! Ou dá ou desce!" - torna-se evidente que o frevo com letra, ou seja, o frevo-canção, resultou de fontes espontâneas, sobretudo dá necessidade de fazer sobreviver a música pernambucana na concorrência das melodias carnavalescas. Mesmo porque, nas ruas, o frevo era eminentemente viril, masculino, somente homem agüentando o repuxo e a efervescência do passo, enquanto nos salões, por sua natureza, a dança não podia apresentar a mesma impetuosidade de ação coletiva, espraiando. Com as damas da sociedade e as mocinhas tentando esquentar os salões do Palacete Azul e do Clube Internacional, nos velhos carnavais das primeiras décadas do presente século, o frevo efeminou-se, sem nenhum sentido pejorativo, nascendo então o frevo cantado, o frevo-canção, tanto para ajustar o passo a homens e mulheres, quanto, paralelamente, no sentido de estabelecer uma confrontação emulatória com a marchinha e o samba do Rio de Janeiro. É claro que nisso tudo entrava um pouco de preconceito de classe: a velha aristocracia procurando fugir à mistura com o populacho das ruas fazendo o seu Carnaval próprio, longe dos empurrões, das inconveniências da mão-boba de um ou outro folião mais atrevido.

Enfim, fatores de ordem econômica e social contribuíram para criar o frevocanção, que é o frevo ortodoxo, na introdução, e um pouco da marchinha carioca, no andamento musical e na elaboração da letra, com seus estribilhos, embora mais ingênuos que maliciosos.

O mesmo fenômeno ocorrera, antes, com o bloco e a marcha-bloco, outras facetas dos clubes e do frevo de rua. Entretanto, os capoeiras, os valentões e o mulherio que não tinham nada a perder, faziam a onda, acompanhando os cordões dos clubes formados por trabalhadores da orla marítima, carvoeiros, varredores da Prefeitura, carregadores e outras camadas do operariado daqueles tempos em torno de organizações cujos nomes pressupunham o caráter másculo de sua composição. Toureiros, Pás de Carvão, Lenhadores, Ciscadores, Ferreiros, Talhadores, Suineiros etc.

A rapaziada - jovens e moças de subúrbios recifenses - instituíam seus blocos, com orquestras de pau e corda. Desfilavam pela capital dezenas e dezenas de violões, bandolins, cavaquinhos, repinicando a introdução do frevo, precedida do apito disciplinador da coreografia coletiva para, em seguida, desaguar na melodia saudosa, cantada por corais de vozes femininas. Os blocos compunhamse de agrupamentos familiares, pais e mães, cuidadosas vigiando as filhas, as meninas-moças, namorados ao lado das namoradas, tudo sob a garantia de poderosos cordões de isolamento que afastavam, às vezes brutalmente, os estranhos e penetras que se iam avolumando rua a fora no itinerário dos blocos, estes sim, de nomes suaves e românticos, muito ao contrário das denominações machistas dos clubes: Bloco das Flores, Após Fum, Amante das Flores, Batutas da Boa-Vista, Batutas de São José, Inocentes do Rosarinho, Madeiras do Rosarinho e Pirilampos. 
Há uns trinta e tantos anos os carnavais do Recife chegaram a ter a participação, durante o dia, de blocos infantis, lindas manifestações de colorido e juvenilidade que o rigorismo das autoridades policiais e judiciárias cancelou sob o absurdo fundamento de proteção aos menores. Quem sabe se desses blocos, de meninos e meninas, não teria saído nova modalidade de frevo, com música e passo próprios da idade? Frustrou-se, dessa maneira, mais uma fonte de criação popular, fenecendo na formação das crianças, o gosto pela música e pelos folguedos carnavalescos da melhor tradição pernambucana.

\section{Saudade (Antonio Maria)}

Ô, Ô, Ô, Ô, Saudade, Saudade tão grande

Saudade que eu sinto do Clube das Pás, do

Vassouras,

Passistas traçando tesouros, nas ruas repletas de lá.

Batidas de Bombo são maracatus

retardados,

chegando à cidade cansados

com seus estandartes no ar.

Não adianta se o Recife está longe,

e a saudade é tão grande

que eu até me embaraço.

Parece que eu vejo Valfrido Cebola, no passo,

Aroldo, Fatia, Colaço,

Recife está perto de mim.

De chapéu de sol aberto (Capiba)

De chapéu de sol aberto,

Pelas ruas eu vou.

A multidão me acompanha.

Eu vou,

Eu vou e venho

Prá onde não sei

Só sei que carrego alegria

Prá dar e vender.

Espero um ano inteiro

Até ver chegar fevereiro

Prá ouvir o clarim clarinar

E a alegria chegar.

Essa alegria que em mim

Parece que não terá fim, mas, se um dia o frevo acabar, juro que vou chorar. 


\title{
Banda de pífanos
}

\author{
RENATO CARNEIRO CAMPOS
}

BANDa de Pífanos, no Ceará, é chamada de Cabaçal; em Alagoas, Esquenta
Mulher; na Paraíba e em Pernambuco, Terno ou Zabumba. Inicialmente, a
função dessas orquestras rústicas, pobres de instrumentos, com os pífanos de
taboca aparentados dos instrumentos de sopro indígenas, era a de tirar esmola
para o Divino Espírito Santo e padroeiras das localidades do interior nordestino.
Usadas, também, nos desfiles das cavalhadas em diversas festas do interior,
invadem casas grandes, capelas sertanejas, juntando moleques atrás delas quan-
do saem nas ruas.

Provavelmente, trata-se de uma herança musical ibérica. Na Espanha, elas acompanham as Pastorales e Vilancicos do Natal. Em Portugal, com o nome de Bombo, estão ligadas às romarias e às cantigas de arraial. Compõem-se, quase sempre, de dois ou três pífanos, três tambores, uma caixa, um tarol e pratos de metal. Há um pífano mais grave e outro mais agudo, como se fossem primeira e segunda flautas. Em Ferreiros, o mestre Ovídio usa duas rabecas em sua orquestra. Geralmente, as músicas não são cantadas. No Terno de Pífanos de Caruaru, no entanto, às vezes intercalam o canto na melodia.

O Quinteto Armorial, que surgiu sob a orientação de Ariano Suassuna, inspirou-se no Terno de Pífanos de mestre Ovídio. Vários temas foram orquestrados, alguns recriados, obedecendo a um tratamento erudito. Um dos temas nacionais, $A$ briga do cachorro com a onça, famoso em todo o Sertão nordestino, aqui no disco é apresentado pela Banda de Pífanos de Caruaru.

Por sua vez, o Quinteto Violado, que tanto sucesso vem alcançando no sul do país, tem também as suas raízes e a sua fonte de inspiração nos modestos Ternos de Pifanos nordestinos.

\section{Emboladas}

\section{EURÍCLEDES FORMIGA}

$\mathrm{T}$ ODA FEIRA NORDESTINA é uma colorida e pitoresca exposição, heterogênea em seus elementos de sabor local, principalmente nas mostras abertas de seu artesanato de cerâmica, cestos, flandres, rendas etc., rudes e maravilhosos resultados de talento dos artistas do sertão, cangaceiros, beatos e cantadores.

Tornou-se famosa a feira de Caruaru, ainda mais depois do baião divulgado 
por Luiz Gonzaga, que não omite os mínimos detalhes daquele espetáculo folclórico do interior pernambucano.

Todavia, uma das atrações mais fascinantes da feira do Nordeste é, sem dúvida, o encontro de dois emboladores, empunhando o pandeiro ou o ganzá (instrumentos de flandre, cheio de caroços de chumbo), desfiando suas rimas com a rapidez de um raio ao calor do desafio, numa autêntica justa sonora, duelo de rapsodos cablocos que aumenta de entusiasmo quanto mais aguçados são os toques de provocação partidos de cada um dos contendores.

A paga é feita pelos circunstantes, que são elogiados ou satirizados conforme a reação ante os apelos feitos pelo embolador, quase sempre estendendo o pandeiro emborcado em evidente cobrança aos espectadores.

O gênero é simples e independente de qualquer composição preestabelecida quanto ao número e disposição dos versos. Há apenas um estribilho, que é repetido com intervalo maior ou menor por um dos cantadores, enquanto o outro improvisa. O metro é setissilábico e a redondilha maior; aliás, o mais comum mesmo entre os cantadores de viola, espetáculo à parte, que já obedece a modalidades diversas e que não é assunto no momento.

Já se disse que o povo de língua portuguesa fala habitualmente em redondilha maior:

- Senhor doutor delegado,

Vim aqui prá lhe dizer

que o meu vizinho do lado...

e vai por aí afora, falante e rimador.

Entre os mais conhecidos emboladores, merece citação especial o TiraTeima, mulato alagoano, dono da extraordinária agilidade mental, hoje radicado em Brasília. Costuma denominar-se de serpente alagoana e afirma quando canta:

- Eu tenho tanto repente

que as vez me faço doente

com preguiça de cantar

Declara com segurança (e todo repentista que se preza faz questão de ter realizado tal proeza) que, certa ocasião, enfrentou o diabo numa peleja, o qual lhe surgiu na forma de uma negra:

- ...num instante eu conheci

que aquela negra era o cão,

o pandeiro caiu da mão

e eu fiz pelo-sinal

Apesar de apregoar seu indiscutível valor, com a empáfia natural dos grandes emboladores, não esquece um desafio que teve com um tal cego João Galdino, 
que o silenciou com um repente magistral:

- Eu sou João Galdino cego

e aonde eu bater um prego

quem vê não pode arrancar.

Os estribilhos da embolada são singelos, harmoniosos. Entre outros, costumam usar os seguintes:

- Lá vem o touro, ô iaiá, com as pontas de ouro

cavando areia no má

- Sabiá da mata.

adeus, sabiá...

voou, avoou,

adeus, sabiá.

O dia vinha raiando,

via o sabiá cantando

nos pés de Nosso Senhor.

- A sulanda não me deu,

Ô sulanda não me dá

Ô sulandá.

Não há, porém, necessidade de ir ao Nordeste para assistir desafio de embolada. Na Guanabara, na feira de São Cristóvão, é comum aparecer uma dupla de repentistas do gênero; também em São Paulo, nas imediações do largo da Concórdia, diariamente se encontram improvisadores, com seu pandeiro e seu ganzá, os alagoanos Januário e Guriatã de Coqueiro.

É justo lembrar aqui que a embolada tornou famoso, nos meios radiofônicos, o pernambucano Manuelzinho Araújo, hoje artista plástico, que trocou o ganzá pelo pincel, sem contudo perder o sabor primitivo do seu talento. Deve-se a ele a divulgação dessa modalidade de cantoria popular nas camadas fora da ambiência sertaneja.

\section{Côco}

RENATO CARNEIRO CAMPOS

Tão é somente o baiano que dá a primeira umbigada. Em quase todo o Nordeste rural, sobretudo nas zonas canavieiras e praieiras, dança-se o côco. A dança começou nos engenhos, de origem africana (Artur Ramos, Mário de Andrade e Câmara Cascudo sugerem também influências ameríndias, provavelmente dos 
Caetés). Antigamente chegou a atingir os salões elegantes de Maceió e João Pessoa, dançado por moças das classes mais altas. Há quem veja nele um feliz cruzamento das músicas negra e indígena. Muitos compositores populares brasileiros têm se aproveitado do côco e da embolada, principalmente em cantigas de carnaval, lançando mão da criação anônima, deturpando-a quase sempre, salvando-se algumas poucas recriações dignas de notas.

O côco é dança eminentemente popular. Há um imperialismo dos instrumentos de percussão, íngonos, pandeiros, cuícas e ganzás. Raríssimas vezes aparecem a viola e o violão. É também chamado de samba, pagode, zambê, bambelô.

O bambelô é uma manifestação típica do Rio Grande do Norte, onde o Quinteto Violado recolheu versos improvisados e refrões. Os instrumentos usados na gravação de estúdio são os mesmos que o povo utiliza nas fontes desta pesquisa: pandeiro, pau-de-semente (ganzá), puita e bobão (surdo). Todas as informações aqui alinhadas a respeito do côco são válidas para o bambelô.

O côco sem coreografia é a embolada. Supõe-se que ele tenha nascido no célebre Quilombo dos Palmares. A música surgiu no ritmo do trabalho de quebrar côcos. Daí a expressão quebrar-côco ter se tornado, posteriormente, não apenas um convite ao trabalho, mas à dança, que geralmente ocorre da seguinte maneira: forma-se roda, no centro da qual fica o tirador de côco, uma espécie de solista, cantando os côcos conhecidos e até chegando a improvisar, acompanhado pelos participantes; depois, os pares fazem voltas e batem palmas, dando entre essas voltas as umbigadas. É um canto social, utilizando sistematicamente - como disse Mário de Andrade - solo e coro.

Atualmente as praias nordestinas formam a área de maior influência do côco. Ainda não decresceu o seu prestígio, sobretudo nas festas de São João e do fim do ano. Pode-se dizer, sem exagero, que se trata de uma das mais expressivas e ricas criações, tanto do ponto de vista musical quanto do coreográfico, do gênio popular brasileiro.

\title{
Bumba-meu-boi
}

\author{
HERMILO BORBA FILHO
}

ATo ou drama pastoril ligado à forma de teatro hierático das festas de Natal e Reis, o Bumba-meu-boi é o mais puro dos espetáculos nordestinos, pois embora nele se notem algumas influências européias, sua estrutura, seus assuntos, seus tipos e a música são essencialmente brasileiros.

Parece que a expressão Bumba-meu-boi origina-se do estribilho cantado, quando o boi, figura principal do auto, dança: Ê! Bumba!, com pancadas do 
zabumba, o que equivaleria a dizer: Zabumba, meu boi, isto é, o zabumba está te acompanhando, boi. Esta engenhosa opinião, com outras palavras, foi emitida por Gustavo Barroso; mas se recorrermos a Pereira da Costa - Vocabulário pernambucano - verificaremos que a palavra bumba significa, na verdade, o bombo ou zabumba, mais exatamente tunda, bordoada, pancadaria velba e, aí, atingimos o seu significado mais essencial, o da pancadaria, porque a maior parte dos espetáculos populares resolve as suas cenas com pancadas.

A origem do bumba-meu-boi perde-se no passado. Não resta dúvida que se trata de uma aglutinação de reisados em torno do reisado principal, que teria como motivo a vida e a morte do boi. O reisado, ainda hoje, explora um único assunto proveniente do cancioneiro, do romanceiro, do anedotário de determinada região. No caso do nosso espetáculo, porém, eles se juntaram para a formação de cenas isoladas, que culminam com a apresentação do boi, mantendo uma linha muito tênue, a do Capitão, servido em suas peripécias por Mateus, Bastião e Arlequim; os diálogos - mistura de improvisação e tradicionalismo - assemelhando-se aos da velha comédia popular italiana; e as músicas, executadas por uma orquestra composta de zabumba, ganzá e pandeiro, ou zabumba, ganzá e reco-reco, ou ainda zabumba, triângulo e rabeca, provenientes das toadas de pastoril, dos reisados, das canções populares, das louvações, das loas, da música popular religiosa.

Tradicionalmente representado durante o Ciclo de Natal, hoje em dia exibindo-se até pelo Carnaval, o espetáculo toma várias designações, conforme a região: Boi-bumbá, no Amazonas; Bumba-meu-boi, e Bois de Reis, no Maranhão e Piauí; Bumba-me-boi, Reisado Cearense, Boi de Reis, Boi Surubi, no Ceará; Boi Calemba ou Calumba, Rei de Boi, Bumba-meu-boi, no Rio Grande do Norte; Bumba-meu-boi, Boi, Bumba de Reis, no Espírito Santo; Bumba-meu-boi e Reis de Boi, no estado do Rio e Guanabara; Boi de Mamão, no Paraná e em Santa Catarina; Bumba-meu-boi, Boi-bumbá e Boizinho, no Rio Grande do Sul.

É um espetáculo praticado em arena, com o público em pé formando a roda que se vai fechando em torno dos intérpretes, até que a Burrinha, o Mateus e mesmo o Boi façam que ela, às custas de correrias e bexigadas, se abra o bastante para a representação poder continuar. Demora normalmente oito horas, não tanto pelo desenvolvimento das cenas, mas sobretudo pela repetição de palavras e passos. Num espetáculo dessa natureza é espantoso como os intérpretes dançam, cantam e representam sem mostra de cansaço, tomando cachaça nas várias saídas de cena. No Boi misterioso do Formigão, no Recife, comandado pelo capitão Antonio Pereira há 68 anos, a máscara é elemento importante e os atores que não a usam lançam mão de maquilagem bem carregada, feita com carvão ou farinha de trigo, assemelhando-se à própria máscara e tem a função de utilizar menor número de intérpretes para o papel de vários personagens.

Os papéis femininos são desempenhados por homens vestidos de mulher à boa maneira dos espetáculos elisabeteanos, exceção feita para a Pastorinha, geralmente uma menina. Outro elemento feminino usado no espetáculo é a 
cantadeira, que se senta ao lado da orquestra entoando loas e toadas para chamar os personagens à cena. $\mathrm{O}$ dinheiro, como a cachaça, é outro elemento constante numa função. Cada ator faz a sua coleta, através de piadas, as mãos estendidas, criando uma representação à parte. $\mathrm{O}$ sistema da sorte, o qual consiste em colocar um lenço no ombro do espectador, que o devolve com uma cédula dentro, nem sempre funciona e, por isso, os atores assaltam o público de mil maneiras engenhosas e cômicas.

Os personagens do auto podem ser classificados em três categorias: humanos, animais e fantásticos. E nas noites do Recife o espetáculo se repete:

Cavalo-marinho

chega prá diante

faz uma mesura

a essa toda gente.

Cavalo-marinho

já pode chegá

que a dona da casa

mandou te chamá.

E na madrugada ouvem-se os últimos versos:

Levanta-te, boi, vamo-no s'embora, que é de madrugada,

o rompê da aurora.

\section{Ciranda: dança popular}

PADRE JAIME C. DINIZ

A lguns pretendem que a palavra ciranda seja de proveniência espanhola. Seria zaranda - nome de um instrumento de peneirar farinha - a sua origem. Leite de Vasconcelos, porém, andou cantando noutro terreiro, quando filiou a palavra ao fato de as mulheres trabalharem juntas em serões, grafando, por esta razão, seranda, e não ciranda.

Pensava-se que a dança da ciranda, no Brasil, estava confinada unicamente ao mundo infantil. Mário de Andrade o asseverou em memória, para o Congresso Internacional de Arte Popular, de Praga, ao escrever que no Brasil "a ciranda é roda exclusivamente infantil". Renato Almeida, por sua vez, afirmava que o referido folguedo "se tornou apenas roda infantil". Entretanto, estudo editado em Recife, no ano de 1960, veio revelar uma ciranda tocada, cantada e bailada 
por adultos de ambos os sexos, numa vasta área de Pernambuco. E já em 1961, a ciranda do mestre Baracho se exibia em festa popular para os recifenses, que até então a desconheciam.

Ao lado das cirandinhas infantis cantadas e dançadas em todo o Brasil, sobrevive no Nordeste a autêntica ciranda. E sobrevive com acentuadas características diferenciais, a começar pela participação dos cirandeiros - os que participam cantando ou dançando, adultos por regra. Difere das cirandinhas pelo repertório variadíssimo no que tange às melodias ou aos textos poéticos, nunca se ouvindo qualquer variante ou reprodução de "ciranda, cirandinha / vamos todos cirandar", pela presença obrigatória de um instrumental no qual o bombo ou zabumba é peça que não deve faltar, instrumental que sustenta o canto da roda ondulante dos cirandeiros, homens e mulheres se alternando, de mãos dadas, não importando qual seja a condição social; difere, também, pelo local de sua execução, que é o terreiro na ponta-de-rua semi-escura ou em lugares mais afastados, sempre ao ar livre. Há ainda, para distingui-la das rodas infantis, a presença do mestre cirandeiro, a quem cabe o ofício de tirar as cirandas (cantigas), improvisar versos, presidir a folgança.

Ao soar forte do bombo, e mais um que outro instrumento, os cirandeiros vão sendo atraídos. Dão-se as mãos, às vezes os braços, espontaneamente, e já estão girando. De meias-luas soltas no terreiro, uma grande roda vai surgindo, num balanço de onda, contagiante. Tão contagiante que faz inveja ao frevo. E todo mundo dança, pois a ciranda não é bailado fechado de um grupo, de alguns pares. É de todos, indistintamente. Assim é que senhoras da sociedade, por vezes de contrato firmado com as colunas sociais dos jornais pernambucanos, podem ser vistas de mãos dadas a mulatos operários descalços, de camisa suada, políticos e professores universitários, ao lado de anônimas empregadas domésticas.

No centro da roda, em cirandas não desvirtuadas do seu habitat, um mastro, um candeeiro (ou um carbureto), o mestre e os seus músicos. Os músicos são os tocadores de bombo, de caixa (sempre atuante nos folguedos populares do Brasil), de ganzá, e de um ou outro instrumento de sopro, como saxofone, trombone, clarineta.

A noite se torna pequena para a animação de uma ciranda. Uma vez iniciada, não se sabe quando termina. Pela madrugada adentro ainda se desfia o rosário das melodias, cantando coisas do mar, coisas da terra, coisas do amor. Rico material que deve ser colhido enquanto é cedo. É o que está fazendo esse admirável Quinteto Violado, ainda tão novo, e já tão forte nos propósitos e nas suas produções, transpondo texto e melodias originais da ciranda para um plano sonoro e atraente, principalmente pela presença da viola nordestina.

Em ambiente no qual se realiza uma ciranda que se preza, nunca falta cachaça, a água que o passarinho não bebe... O dono da ciranda - ou dona (quem em geral a promove) é algum proprietário de restaurante, bar ou simples boteco, onde o mestre cirandeiro, sem falar nos demais participantes, sobretudo 
os músicos, pode encher a cara, se desejar... Quanto mais quente o mestre, mais inspirado para os improvisos, mais concentrado em sua arte, mais sua voz ressoa forte e resistente.

Já nos ambientes mais sofisticados do Recife (Pátio de São Pedro / boates, salões de dança, colégios e até residências) nos quais, hoje, também chega a boa ciranda, a cachaça pura e saborosa se desvirginaliza transmudando-se em batida, batida de limão, batida de pitanga, batida de maracujá.

Não há estações próprias para a ciranda. Dança-se durante todo o ano. Aos sábados e domingos preferencialmente, quando se procura esquecer tanta labuta, tanto pão suado, tantas preocupações. Os versinhos colhidos já há alguns anos, falam a respeito: "Carnavá é todo ano / E ciranda, quarqué um dia".

\begin{abstract}
A s Fotografias que ilustram $O$ Nordeste e sua música nos foram cedidas pela Discoteca Oneyda Alvarenga, da Divisão de Bibliotecas do Centro Cultural São Paulo. Pertencem ao acervo da Missão de Pesquisas Folclóricas. Para resgatar a memória da Missão, o Centro Cultural São Paulo publicou em 1985 um trabalho de Flávia Camargo Toni, do qual extraímos o seguinte trecho:

"O Brasil realmente não conhece a sua música nem seus bailados populares porque, devido à sua enorme extensão e regiões perfeitamente distintas uma da outra, ninguém, nenhuma instituição se deu ao trabalho de coligir esta riqueza até agora inativa".

A citação, de Mario de Andrade, definiu o objetivo da Missão de Pesquisas Folclóricas, expedição realizada em fevereiro de 1938 por Luís Saia, Martin Braunwiser, Benedicto Pacheco e Antonio Ladeira pelo Norte e Nordeste brasileiros, último trabalho realizado pelo Departamento de Cultura, na época chefiado por Mario de Andrade. Ele, ao lado de Oneyda Alvarenga, diretora da Discoteca Pública Municipal, órgão ligado à Divisão de Expansão Cultural, também chefiada por Mario, empenharam-se para que a Missão fosse um sucesso. Mario de Andrade, na orientação metodológica do grupo e Oneyda, na organização do material coletado. Os quatro elementos prepararam-se para gravar, filmar, fotografar e descrever o maior número possível de manifestações populares que fossem encontrando nas cidades que percorreram.
\end{abstract}

A Missão visitou cinco cidades em Pernambuco, 18 na Paraíba, duas no Piauí, uma no Ceará, uma no Maranhão e uma no Pará. Assistiu a representações de Bumba Meu Boi, Nau Catarineta, Cabocolinho, Maracatu, Tambor de Crioulo, Tambor de Mina, Praiá, anotou versos de poética popular, dados sobre arquitetura e ganhou muitos objetos. Ao regressarem, Oneyda Alvarenga sistematizou boa parte das informações em publicações feitas pelo Departamento de Cultura e organizou o Fichário Folclórico da Discoteca. 
FREVO (RECIFE, PE)
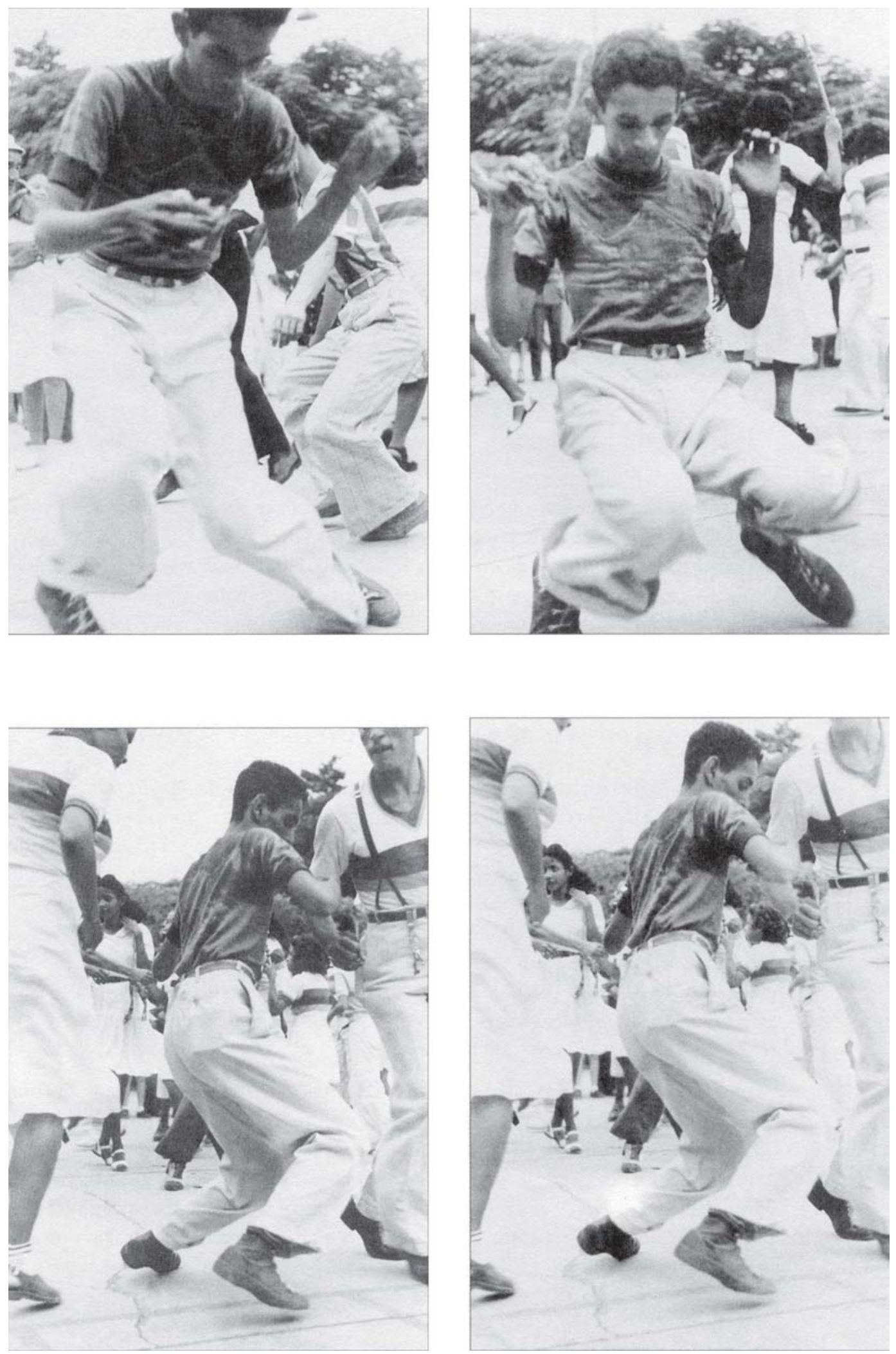


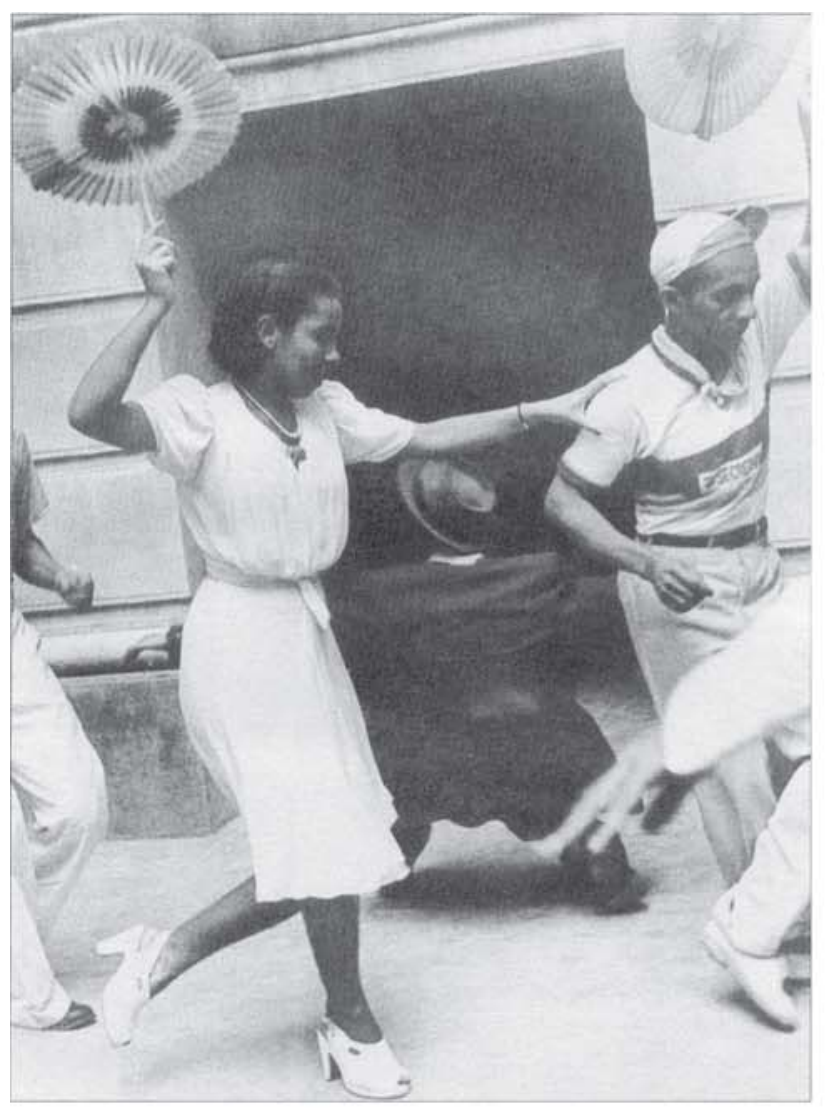

FREVO (RECIFE, PE)

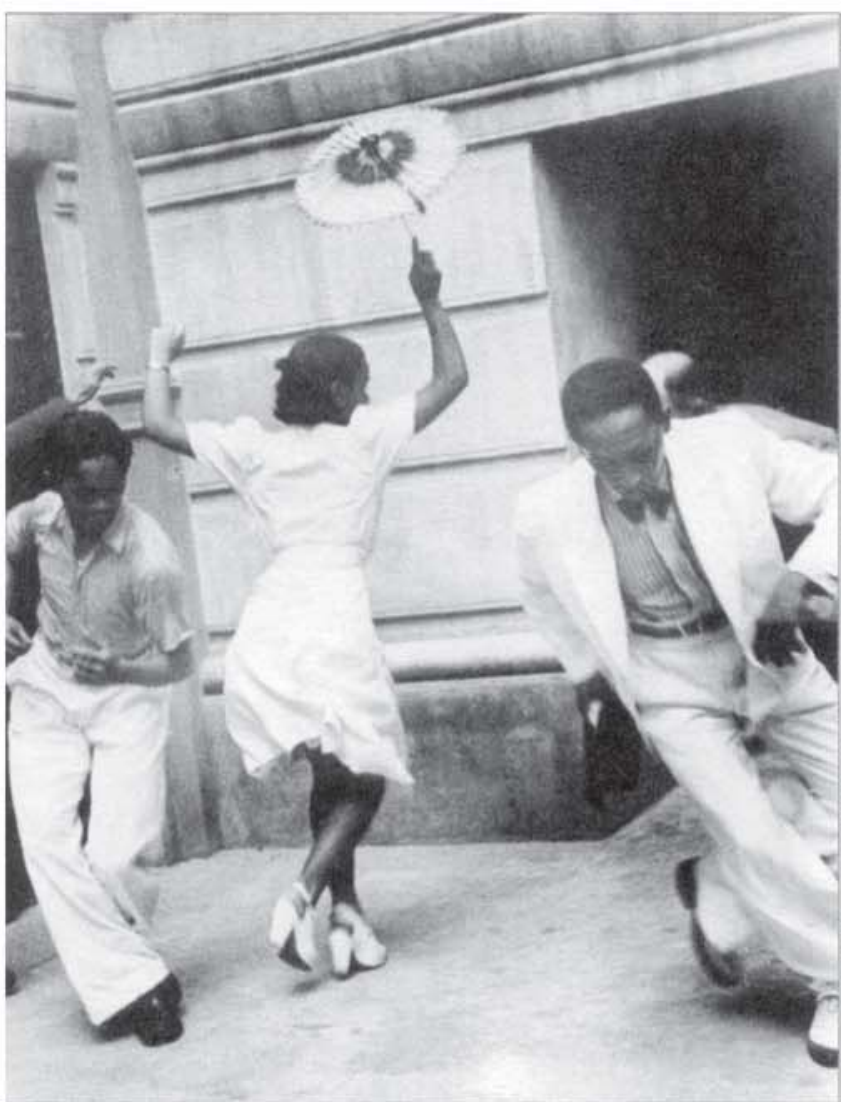


RODA (PATOS, PB)
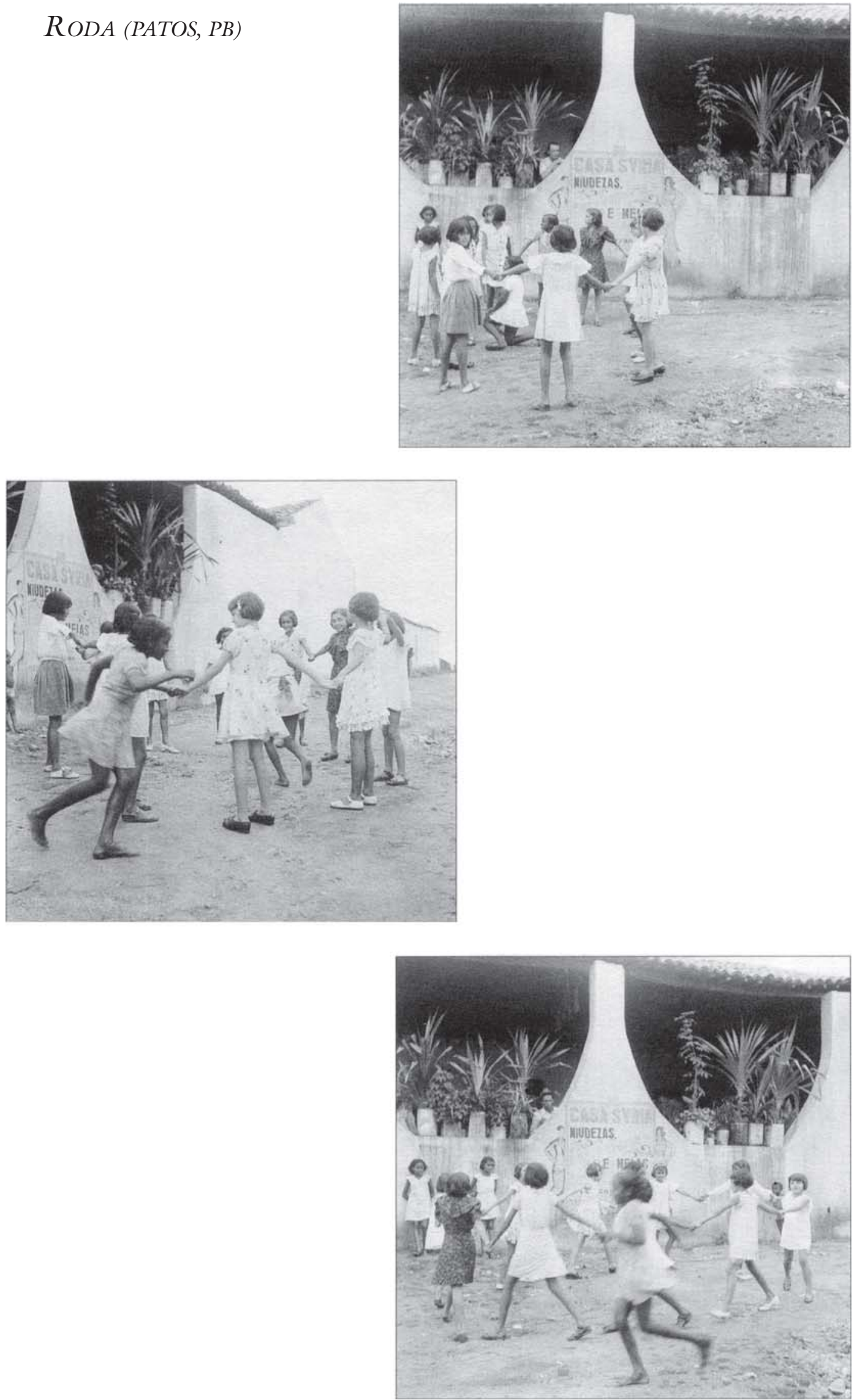
BUMBA MEU BOI (PATOS, PB)
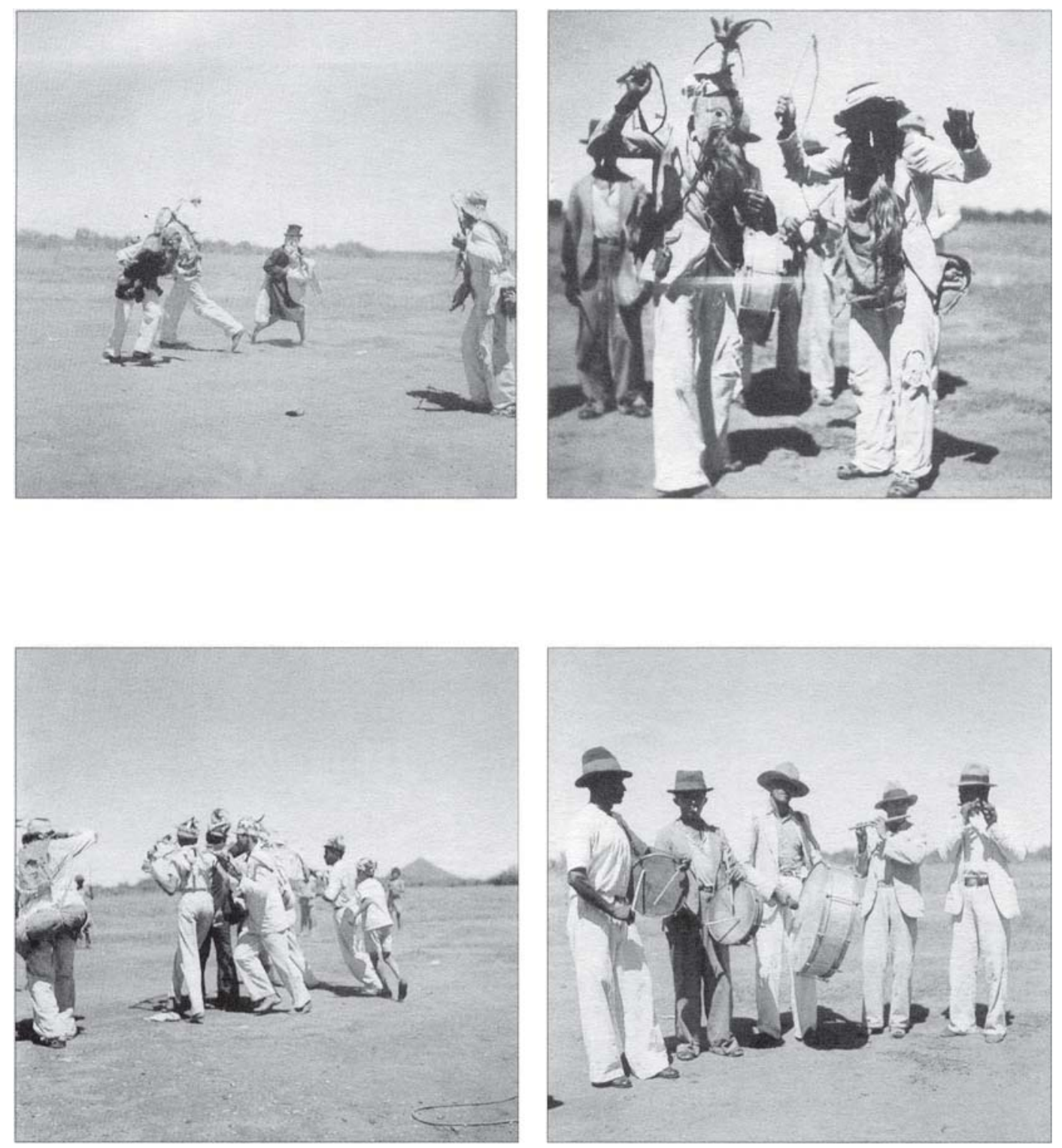


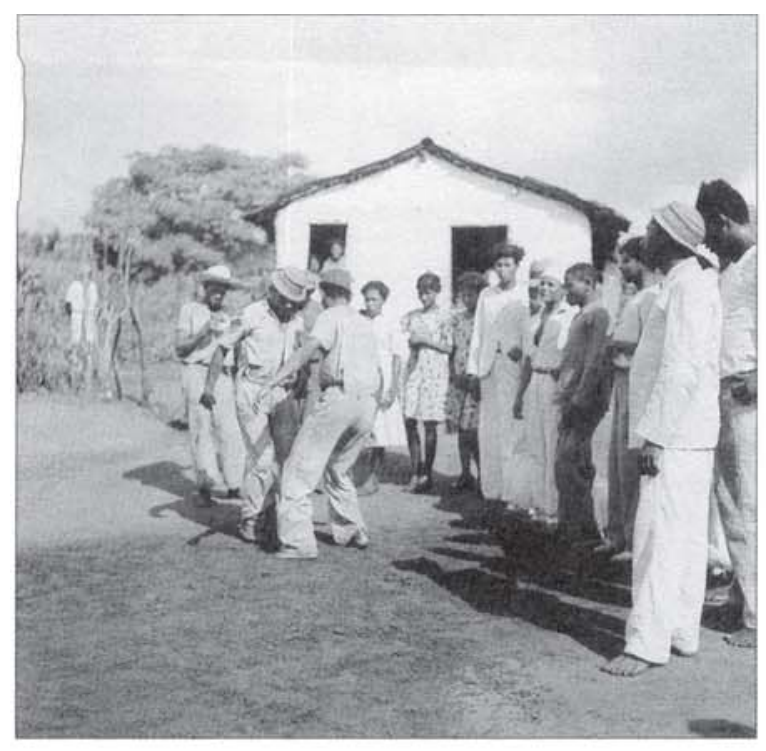

CÓCO DE RODA

(ITABAIANA, PB)
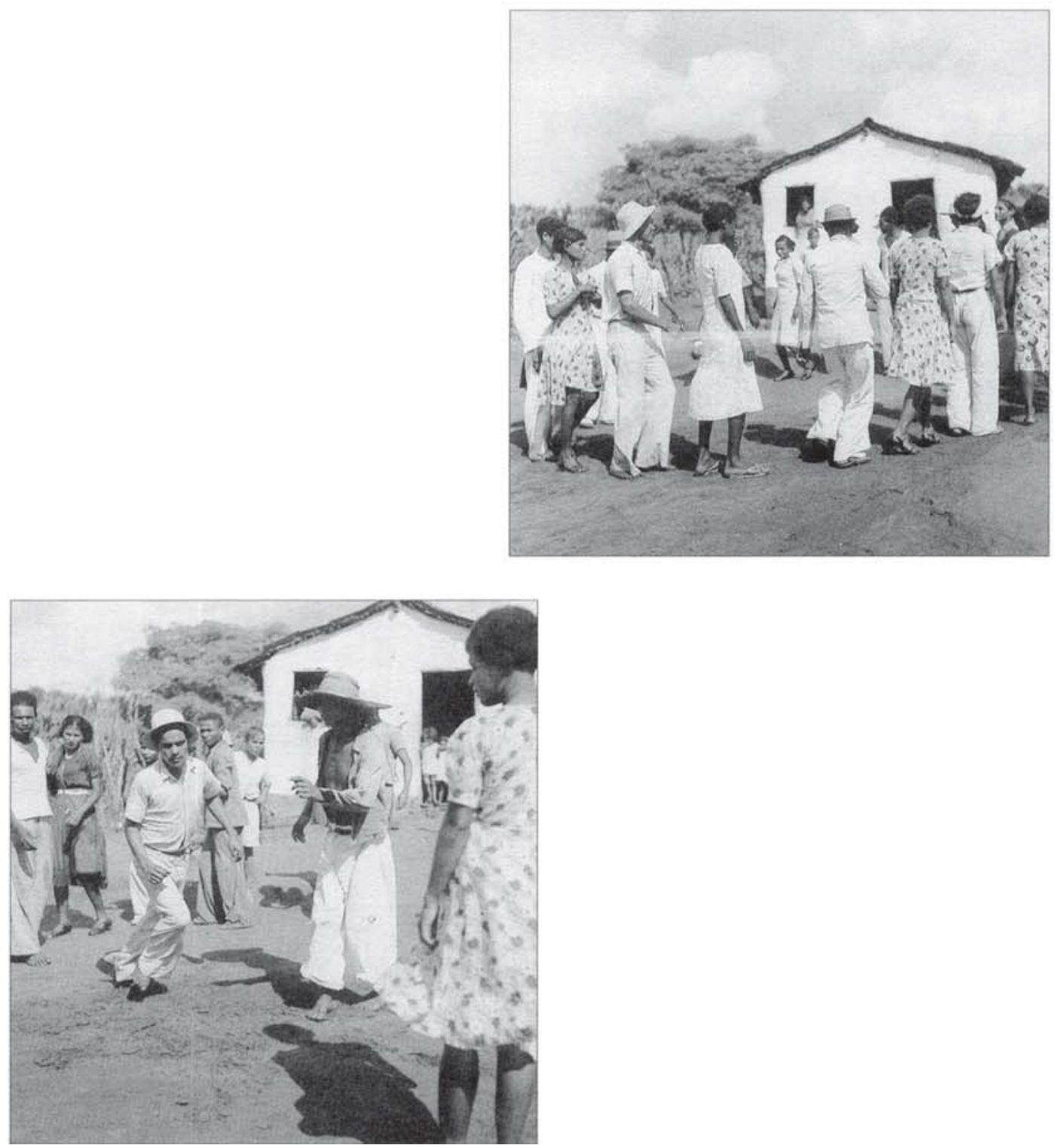


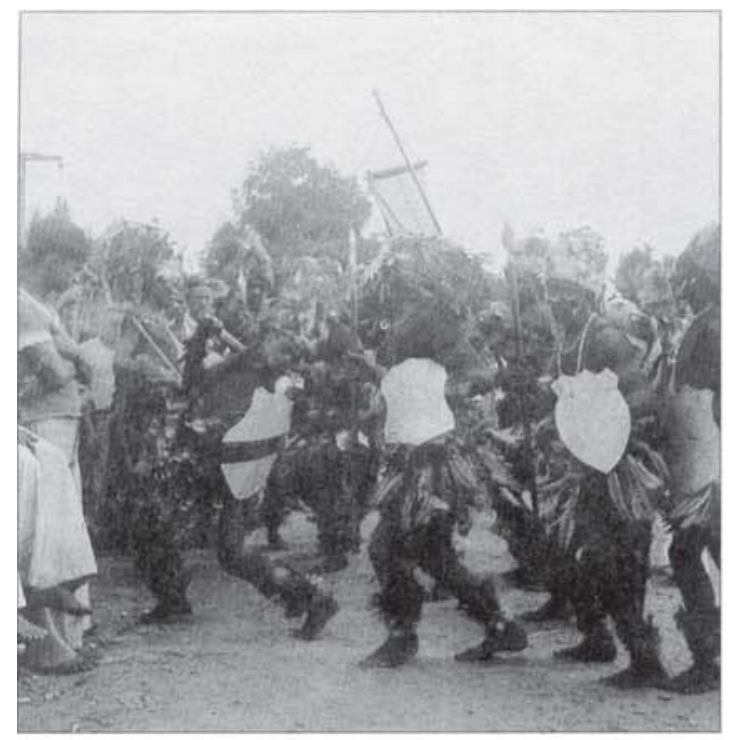

CABOCOLINHOS

ÍNDIOS AFRICANOS

(TORRELÂNDIA, PB)
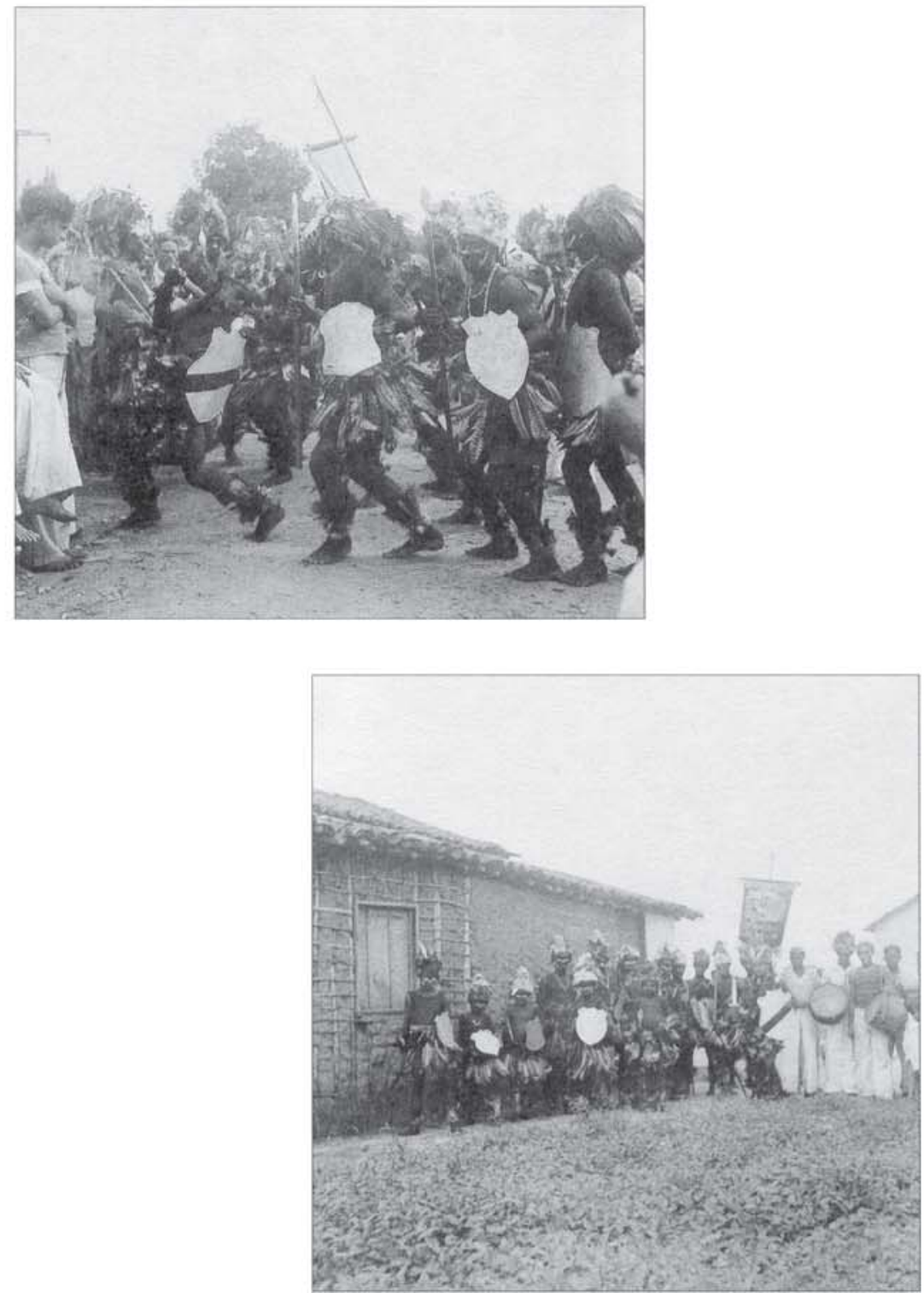

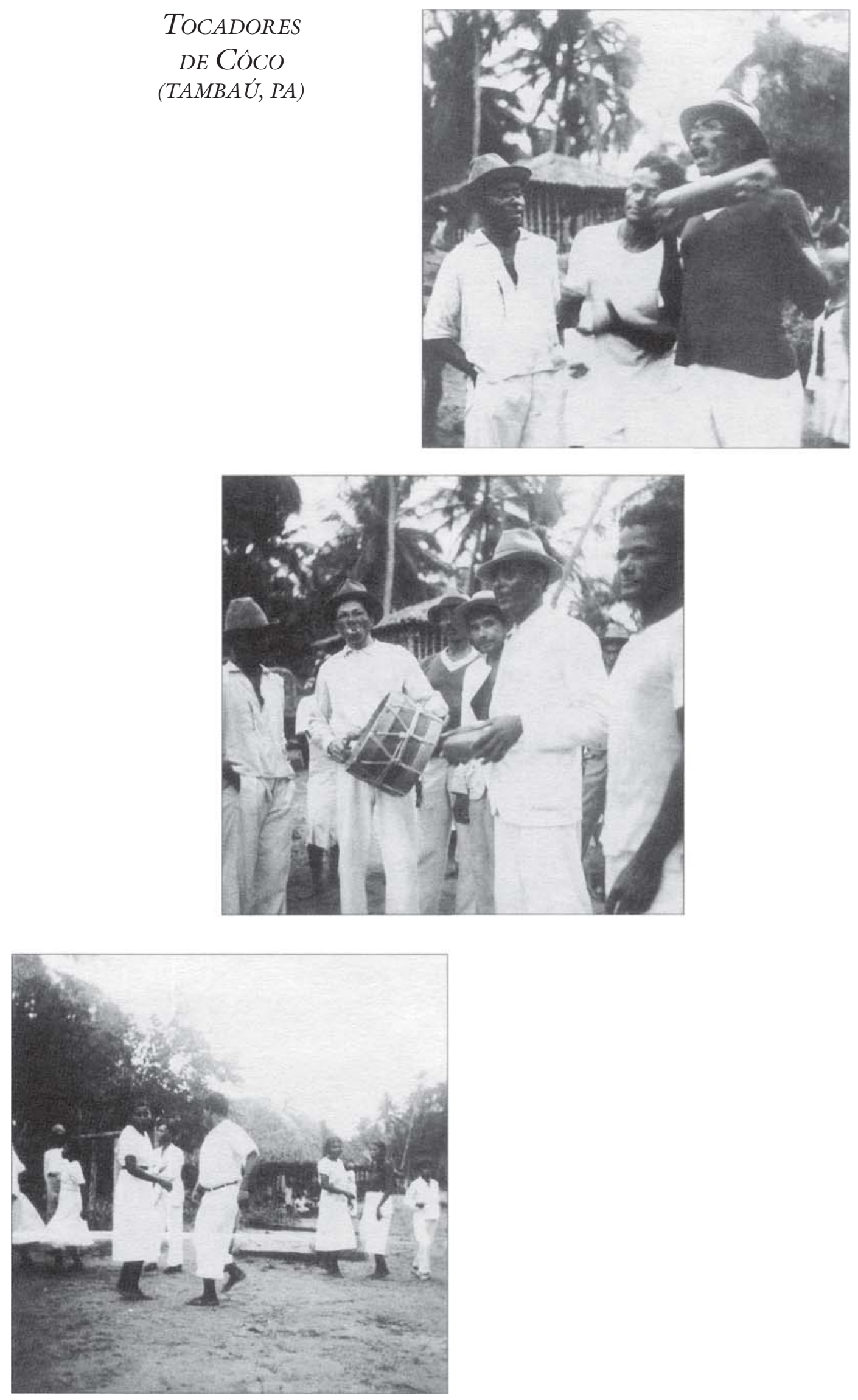